\title{
Politics of Belonging: A Narrative on Activism in Sweden
}

\author{
Aleksandra Ålund \\ Journal Article
}

\section{Tweet}

N.B.: When citing this work, cite the original article.

This is a postprint version of an article published in:

Aleksandra Ålund, Politics of Belonging: A Narrative on Activism in Sweden, NORA, 2014. 22(4), pp.330-337.

NORA is available online at informaworldTM:

http://dx.doi.org/10.1080/08038740.2014.965199

Copyright: Taylor \& Francis (Routledge): SSH Titles

http://www.routledge.com/

Postprint available at: Linköping University Electronic Press

http://urn.kb.se/resolve?urn=urn:nbn:se:liu:diva-116782

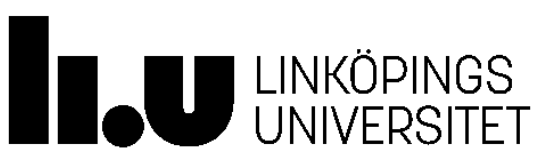


Published in: Ålund, Aleksandra (2014) "Politics of Belonging: A Narrative on Activism in Sweden", NORA - Nordic Journal of Feminist and Gender Research, 22:4, 330-337

\title{
Politics of belonging: A narrative on activism in Sweden
}

\author{
Aleksandra Ålund, REMESO, Department of Social and Welfare Studies, Linköping \\ University, Sweden
}

\begin{abstract}
Intersectionality is commonly used as an analytical tool to bring to light how various social divisions merge to produce a cohesive set of subordination practices, but not as often, how the concept can be used in the study of agency. Discussing politics of belonging through cases of urban justice movement in Sweden, the article focuses on intersectionality as a perspective interlinking different dimensions of power with agency; thus the aim is to analytically highlight the interconnection of agency with subordinating power dimensions, creating a basis for resistance. This is illustrated with examples on movements for social justice, opposing racism, sexism and class oppression. The article discusses their collective mobilization and claims for public voice. Using one activist's narrative about how the subjectivity denied to citizens can be recaptured; the author demonstrates how reflexive self-awareness becomes connected to politics of belonging, expressing how the personal becomes political.
\end{abstract}

Key words: activism, urban justice movements, racism, intersectionality, subjectivity

Contemporary youth rebellions in European cities - like Paris 2005, Copenhagen 2008 and London 2011 - have sparked vociferous debates on urban unrest across Europe, addressing the issues of mobilization and resistance, lack of an inclusive citizenship, decline of social welfare and democracy. In Sweden, as elsewhere, urban unrest has been expressed through sporadic violent acts of setting cars and schools on fire and in local confrontations with the police. A fullfledged "riot” spread across disadvantaged neighborhoods of Swedish cities in 2009 (Schierup \& Ålund 2011) and again in May 2013 in Husby, a multiethnic suburban neighborhood of Stockholm (Schierup, Ålund and Kings 2014).

After the 2009 rebellions, new urban justice movements, keen to argue rather than fight, emerged. The most prominent became the Megaphone (Megafonen) in Husby/ Stockholm ${ }^{1}$ and the Panthers (Pantrarna) ${ }^{2}$ in Gothenburg. They are concerned with segregation, social inequality and racism and focus on claims for civil and human rights, participatory democracy and renewal of disadvantaged suburban neighborhoods. They represent a grassroots mobilization that interconnects spatial with social (in-)justice and addresses issues of segregation, racism and welfare transformation (Schierup et al 2014). 
With similar goals, a spectacular initiative, FORIX, Förorternas Riksdag ${ }^{3}$ (The Suburban Parliament), functioned, particularly during 2012, as a forum for critical debate and provided a scene for alternative suburban cultural expression. Let me begin with a few reflections on a cultural event “The suburb takes a stand against segregation” (Förorten tar ton mot segregation) organized by FORIX, which took place in January 2012 at the Orion Theatre in Stockholm. ${ }^{4}$ Hundreds of young people filled the theater and well-known hip-hop artists expressed their perception of suburban life. The debate among hip-hop artists gave a good impression of what it is about. As one rap artist put it:

I think it is important that we as a minority population in Sweden are taking matters into our own hands when we are excluded from the political debate and not represented properly in parliament and at the national level. It is important that we ourselves create our own forum where we can express our own opinions and talk about issues that concern us and that are usually not addressed in the political agenda, or in the media and in political debate. (Carlito, 2012; Quotes 1-6 have been translated from Swedish into English by the author) [Quote 1]

Here the experience of marginalization and the need for a voice of their own in public discourse are depicted. Building on this momentum, I shall, in the following, present one well-known member of the Megaphone, Rami Al-khamishi. In recording his narrative, I wish to emphasize the importance of developing an intersectional perspective focused on the agency, interconnectedness and situated knowledge rather than the stockpiling of subordinating dimensions of power.

\section{The resistance of subordinated people; agency, interconnectedness and situated knowledge}

Intersectionality is commonly used as an analytical tool to bring to light how various social divisions join together to produce a cohesive set of subordination practices but also, though not as often, how the concept can be used in the study of agency. In this latter meaning, Floya Anthias points out that it is important not to focus on the intersection of different subordinating dimensions of power since there is a risk of construing individuals as belonging to fixed and permanent social groups. Instead, the focus should be on intersecting experiences among social actors, which bring forward active subjects and their mutual relationships. A 
similar perspective is used by Kum-Kum Bhavnani (et al. 2003: 11), who proposes the concept of interconnection (rather than intersection); referring to interlacing power relations, subordination and resistance, with active subjects as the focus of analyses.

Anthias (2002: 501) discusses identity formation among youth from migrant backgrounds using narrative as forms of social action, showing how human subjects construct themselves as social actors; as "actively participating in the very construction of subject positionalities". Identity needs to be seen as situated in social contexts, including location and social position/positioning. Narratives of location are also narratives of "dislocation and alterity" (Anthias 2002: 499), connecting issues of belonging to social exclusion/inclusion, as well as social mobilization and resistance.

When de los Reyes \& Mulinari (2004: 118-119) address the importance of bringing to light the resistance of subordinated people and their attempts to articulate their own narratives and frames of interpretation, this accords with my understanding. When the intersection of social and spatial inequality becomes conceptualized as a subjective experience, expressed in visions of the need to recapture denied subjectivity through self-awareness and collective struggle, then politics of belonging are in the making.

Thus, to paraphrase the notion of interconnection, I use intersectionality as an analytical concept linking interventions on activism from Anthias and Bhavnani, with what Kimberlé Crenshaw (2011: 232) refers to as “...situated knowledge to construct understanding out of social contradictions". In the following text, the latter formulation is applied as analyses of contradictions between belonging and exclusion; reading dislocation and alterity among young urban activists for social justice; their reflections on prospects for solidarity; imagining a homeland as free from racism through narrative on transgression of stigmatized belonging in Sweden - and occasionally, as will be illustrated below, experienced in a joint youth mission outside Sweden.

\section{A Megaphone for alternative voices}

I shall focus on the Megaphone as this case exposes the interconnection of place-based livelihoods, emerging modes of civic agency and wider structural-institutional conditionality. The organization combines local rootedness with national networking by extending their activities to other cities. It collaborates with various movements for justice in Sweden, forges alliances with other civil society actors, and articulates goals and visions in broad public 
contexts. It began to take off in the Husby neighborhood of Stockholm in 2008/2009 as a reaction to a stigmatizing media report on the murder of a Husby youngster, Ahmed Ibrahim Ali. Nicknamed Romário, he was a well-known football player in the area, but in connection with circumstances concerning his murder the mass media referred to him, according to the stereotype of suburban youngsters, as a criminal and a gang member. During approximately three years, the Megaphone has expanded geographically in the North West of Stockholm and in numbers of sympathizers, activists and participants. Education through individual assistance, study-groups, movie seminars and discussion meetings, directed towards both youth and adults, constitute the foundation of their work. It provides a critical voice in the mass media, and is present at public demonstrations and conferences on urban issues. Autonomy in relation to political parties and the state is seen as essential, both in terms of legitimacy and actual capacity for defining independent agendas.

\section{The personal becoming political; narrating the experience of being singled out, disconnected and re-connected}

With Rami’s permission, fragments of his Facebook narrative will be a starting point in the following. Being one of the publically well-known representatives of the Megaphone, he recounts how he and his comrades are fighting against the withdrawal of welfare in the suburbs. They help young people with homework and form alliances with other neighborhoods and cities. In other words, they epitomize how a social movement grows as a reaction to welfare cuts in the wake of neoliberal economic interventions, which result in the privatization of housing, the closure of health centers, libraries, youth centers, etc. Rami tells us about experiencing individual and collective stigmatization, the lack of a public voice in political spheres where ongoing urban transformations are negotiated, and the feeling of hopelessness in relation to the established popular movements and political parties among suburban youth. He tells us, furthermore, how his individual experience conveys the prospects for possible dialog

On his Facebook page, Rami writes about the vulnerability that he experienced as a "special kind" of Swede, being insulted at the airport while journeying abroad as member of a group of young Swedes making an official visit to a south-eastern European country. Rami's report on this journey exposes his doubts about his Swedishness. At first he speaks impulsively, then with some consideration and finally relates how dialog is possible. 
There is something special with me at airports. A passport control occurs only for me. I was stopped and asked to show my passport to the guard. Questions... I ask him why he was watching me, or did he think it's okay to check only me because I look the least Swedish in appearance? I was disappointed at some of our group and said afterwards what I thought of their passive behavior. They tried to calm me down... But I've been through this before. The airport bus drops us off 40 feet away from the plane. I am the last in line and barely have time to climb the stairs. Then again a guy working at the airport comes up and asks me to show my passport again. One hundred and fifty people just went through, the six Swedes in the same group as me passed... I am thinking, 'you have not even looked at them. Enough! Why are you looking only at me and no one else?’ [Quote 2]

After this introduction, Rami takes up the subject of how his Swedishness becomes confirmed, how solidarity can contribute to feelings of belonging:

Just then, something happened that taught us all lessons, not only me but about all Swedish people! Nearly all the Swedes already on the plane came outside to me. They calmed me down, and explained to the airport guy that I had already been stopped at passport control... 'Is it due to my appearance?' They do not accept his behavior. This is an important lesson to take with me; how racism expresses itself in this world, whether you are in a restaurant queue in downtown Stockholm, or in an airport halfway around the world, where one guy stops me and tries to show off his own importance. [Quote 3]

Then Rami muses on how the personal and the political can be brought together:

There is a world order in which the white man from the West is considered to be superior, the norm, the intelligent and privileged. Where the non-whites are inferior, constantly challenged, worthless and can be treated in any old way. Racist communities and discriminating structures have historically been built up, hierarchically, and must be fought everywhere in the world. Both in our suburbs and beyond. [Quote 4]

Situated knowledge has many connotations. In his reflexive analysis, Rami connects his personal experience with collective experience of subordination and calls for resistance, while presenting a vision of Swedishness in an inclusive homeland: 
The world would feel better if more people dared to speak up and risk getting crap in return. Now it was me, but more importantly white Swedes, although they were not stopped or disgraced, took responsibility for the injustice they saw and dared to confront it and take sides. Now they confronted racism head on. They saw my frustration and vulnerable position and compared it with their own. It was a fact that although citizenship, language, and my clothes were 100\% Swedish, just like theirs, I was nevertheless treated differently based on appearance! You can either let it go on, shut up and pretend that ‘nada' (nothing) has happened, or you confront it. Either you continue to dream of a society without racism or you rebel against it. [Quote 5]

And it is here that a vision of how another world is possible becomes articulated with a focus on solidarity and opposition to racism:

If people reacted more frequently regardless of whether they are directly exposed or not, racists might find it a little harder to be racist. Everyone can play a role whether you are a wog or a Swede. One of the companies that I traveled with during the week and who reacted at the airport, wrote a letter the day after we arrived home to tell the airline about how the staff behaved and that the company should explain itself. Such people grow in my view. It was not that this person did this for me; ...I could have done it myself ...but what happened had affected me and upset her greatly. She reacted when racism manifested itself so clearly that no one could deny it. [Quote 6]

Rami's narrative shows how the resistance to stigmatization and subordination has to be connected to a globalized discourse and practice about the siege of the Others, especially Muslims, in times of more pronounced political concern about security, in the aftermath of the September 11, 2001 incident in New York and the subsequent War on Terror. In his narrative, he intertwines thoughts on Swedishness with public political discourse that appeals to the nation's cohesion, which since the early 1990s is characterized by demands for shared cultural value systems, while differentiating between us and them in terms of culture in the labor market, the educational system, by increased segregation, etc. (Schierup and Ålund 2011). The discursive positioning of individuals and groups as the Others, as immigrants, occupies the center of Rami's reasoning on racialized differentiation of citizens and the need for civic resistance.

His personal narrative spills into, or rather illustrates, the complexity of activism for full 
citizenship; concerning the Megaphone's aims to reclaim the city/suburb, as a means of revamping the welfare regime and rescuing Swedish 'exceptionalism'. It is here that we can see an example of how his narrative reflects the wider context of "inequality, constructed in the intersection between different levels of society and subordination that occurs at the intersection of power structures, institutional practices and individual actions” (de los Reyes and Mulinari (2005: 9). While Rami’s story illustrates a personal experience it represents an activist counter narrative that speaks about how the personal becomes the political. Let us now turn to the wider political frames of these kinds of politics of belonging.

\section{Urban justice movements}

Mustafa Dikeç (2007) analyses urban rebellion in France in his book Badlands of the Republic and demonstrates that marginalized districts are increasingly considered "badlands" in public discourse and, thereby exposed to repressive forms of state intervention.

This development is related to the increasing neoliberal orientation and "a retreat of the state from the social in the domain of urban policy” (op.cit.: 124). There are apparent Swedish parallels with this urban policy development, although not as dramatic as in France. "Whereas the urban policy neighborhoods were sites of political experimentation in the early 1980s, starting with the mid-1990s they have become sites where the republican penal state has consolidated itself” (op.cit.: 126). A report on Rosengard, in Malmö, commissioned by the then Swedish Integration Minister Nyamko Sabuni from the National Defense College (Ranstorp and Dos Santos, 2009), may especially illustrate how Sweden carries similarities to what Dikec refers to as securitization. With reference to France, he claims that cities are potential or actual sites for political mobilization driven by democratic ideals (Dikeç op.cit.: 173). He sees contemporary youth rebellions in France, but also in European cities in general, “not merely as intrinsic acts of violence” (op.cit.: 148) but as responses to structurally embedded processes of segregation, unemployment, ethnic discrimination and welfare cuts. Urban revolts are, he argues, “justice movements” that question spatial and social injustices embedded in wider political contexts.

Dikeç emphasizes the importance of recognizing activist groups as articulate movements aiming for deliberative dialog - often rendered invisible in public discourse, in favor of attention to the "noise" of spectacular revolts. The Megaphone is an "articulate" urban justice movement (Schierup, Ålund and Kings 2014). 
With self-understanding as part of Sweden's “new popular movement” (den nya folkrörelsen), The Megaphone, formulates its objectives as follows: working for social justice in Sweden through organizing young people in the suburbs, in a society where everyone has equal opportunities and is included in all important political decisions; a society with collectively owned municipal services as opposed to a massive clearance sale of public property; the making of a society for all free from racism, sexism and class-oppression ${ }^{5}$ through mobilizing the power to which repression in suburbia gives birth.

This goal condenses the introductory reflections on intersectionality as a means of analytical interconnection of subordinating power dimensions creating a fundament for resistance. In their claims for social justice, the Megaphone illustrates how politics of belonging express connection between citizenship rights, access to welfare and place struggle.

Rami's narrative illustrates how denied subjectivity can be recaptured; how solidarity is perceived and how reflexive self-awareness becomes included into politics of belonging, expressing how the personal becomes political.

\section{Notes}

${ }^{1}$ http://megafonen.com/ Accessed: 1 September 2014

2 https://sv-se.facebook.com/pantrarna.upprustningavfororten Accessed: 1 September 2014

3 http://forix.se/Accessed: 15 January 2013

4 Hiphop, poesi \& politik - FÖRORTEN TAR TON MOT SEGREGATION: den 18 februari 2012, https://sv-se.facebook.com/events/208443532587437/Accessed: 15 January 2013

${ }^{5}$ http://megafonen.com/om Accessed: 1 September 2014

\section{References}

Anthias, F. (2002) Where do I belong? Narrating collective identity and translocational positionality. Ethnicities. 2(4): 491-514. doi: 10.1177/14687968020020040301

Anthias, F. (2004). Begreppet 'translokalisering' och teorier kring social stratifiering: Frågor om genus, etnicitet och klass [The concept of 'translocation' and theories of social stratification: Questions about gender, ethnicity and class]. In: K. Mattsson \& I. Lindberg (Eds), Rasismer i Europa: Arbetsmarknadens flexibla förtryck [Racisms in Europe: the flexible oppression of the labour market]. ( pp. 193-219). Stockholm: Agora.

Bhavnani, K-K., J. Foran \& P. Kurian (Eds.). (2003). Feminist Futures: Re-imagining Women, Culture and Development . London and New York: Zed Books.

Carlito (2012). Performance at FORIX, Orionteatern event Hiphop, poesi \& politik FÖRORTEN TAR TON MOT SEGREGATION: den 18 februari 2012, https://svse.facebook.com/events/208443532587437/ Filmed speech http://www.youtube.com/watch?v=xwRSv8pVLiI Accessed 15 January 2013 and 1 September 2014 [Hip Hop, Poetry \& Politics: The suburb takes a firm stand against segregation. February 18, 2012, Stockholm]. 
Crenshaw, K. (2011) Postscript. In: H. Lutz, M. T. Herrera Vivar \& L. Supik (Eds.), Framing Intersectionality: Debates on a Multi-Faceted Concept in Gender Studies. (pp. 221233). Ashgate.

de los Reyes, P. \& Mulinari, D. (2005) Intersectionality - Critical reflections on the (in) equality landscape. Malmö: Liber AB.

Dikeç, M. (2007) Badlands of the Republic: Space, Politics and Urban Policy. WileyBlackwell.

FORIX http://forix.se/

Megafonen http://megafonen.com/om

Pantrarna https://sv-se.facebook.com/pantrarna.upprustningavfororten

Ranstorp, M. \& J. Dos Santos (2009). Hot mot demokrati och värdegrund - en lägesbild från Malmö [Threat to Democracy and the Value Basis - a status report from Malmö]. Stockholm: Försvarshögskolan, FHS/CATS RAPPORT 2 (37) 2009-01-28. Stockholm: National Defense College.

Schierup, C.-U. \& A. Ålund (2011). The End of Swedish exceptionalism? Citizenship, neoliberalism and politics of exclusion. Race \& Class. 53 (1):45-64. doi: 10.1177/0306396811406780

Schierup, C.-U., A. Ålund \& L. Kings (2014) Reading the Stockholm riots - a moment for social justice? Race \& Class. 55 (1):1-21. doi: 10.1177/0306396813509191 